\title{
Peningkatan Kemampuan Penyusunan Instrumen Evaluasi Berbasis Hots Bagi Guru (SMAN 05 Tinggi Moncong)
}

\author{
Netti Herawati ${ }^{1}$, Muhammad Anwar ${ }^{2}$, Ahmad Fudhail $^{3}$ \\ 1,2,3 Jurusan Kimia, FMIPA, Universitas Negeri Makassar
}

\begin{abstract}
The implementation of this Community Parthnership Program, PkM aims to improve the understanding of SMAN Negeri 05 Tinggi Moncong teachers about the principles and steps of developing HOTS-based evaluation instruments, the format and components of HOTS-based evaluation instruments, and skilled in preparing HOTSbased evaluation instruments, with a minimum target of $90 \%$ of participants of PkM training is able to prepare evaluation instruments well. The implementation of this activity involved three lecturers from the Department of Chemistry, Faculty of Mathematics and Natural Sciences, Makassar State University, with a background in chemistry and chemistry education. The method applied in the implementation of this PkM is by applying various methods of presentation or lectures, question and answer, discussion, and practice / performance. Then it was continued as an independent assignment outside the classroom for 5 days. All of these activities were carried out online due to the COVID 19 pandemic conditions. This activity succeeded in improving the ability of SMA 05 Tinggi Moncong teachers in developing HOTS-based evaluation instruments.
\end{abstract}

Key Word: HOTS,PkM, Evaluation

\section{PENDAHULUAN}

Pada pelaksanaan Ujian Nasional 2018 untuk Sekolah Menengah Atas (SMA) dan Madrasah Aliyah (MA) dikeluhkan mengenai sulitnya soalsoal yang diberikan. Kementerian Pendidikan sudah mulai menerapkan standar international yang memerlukan daya nalar tinggi atau High Order Thingking Skills (HOTS). Peserta didik diharapkan mencapai berbagai kompetensi yang sesuai dengan HOTS. Kompetensi tersebut adalah berpikir kritis (critical thingking), kreatif dan inovasi (creativity and innovation), ketrampilan berkomunikasi (communication skill), keterampilan bekerja sama (collaboration), dan kepercaan diri (confidence). Kelima keterampilan ini merupakan kecakaan siswa yang diperlukan dalam abad ke 21 . Peningkatan keterampilan tingkat tinggi ini juga diharapkan dapat meningkatkan peringkat peserta didik Indonesia pada lembaga pemeringkatan international seperti PISA (Programme for International Students Assessment dan TIMSS (Trend in International Mathematics and Science Study (Ariyana, Pudjiastuti, dan Bestary, 2018)

Guru sebagai pendidik memiliki peran yang sangat penting yang menetukan keberhasilan peserta didik. Guru memiliki kedudukan yang sangat strategis untuk dapat mengambil keputusan dalam melaksanakan proses pembelajaran. Guru diharapkan dapat merencanakan pengalaman belajar yang akan ditumbuhkan kepada peserta didik, membimbing peserta didik, mengorganisasi sistem pembelajaran di kelas, mengevaluasi dan banyak lagi hal yang lain (Furchan, 1982). Guru menentukan keberhasilan peserta didik dalam pembelajaran. Untuk mempersiapkan peserta didik agar keterampilan berpikir tingkat tinggi mereka dapat meningkat maka guru perlu dibekali dengan pemahaman dan keterampilan dalam mengajar. Ada tiga kegiatan pokok yang dilakukan oleh guru dalam mengajar yaitu: merencanakan, melaksanakan, dan mengevaluasi. Ketiganya merupakan hal yang sangat penting dan saling terkait.

Hasil observasi dan wawancara dengan beberapa guru di SMAN Negeri 05 Tinggi Moncong menujukkan bahwa pembelajaran di sekolah tersebut telah menggunakan kurikulum 2013 dan pelaksaan pembelajarn dilakukan dalam 5 hari kerja. Meskipun mereka telah menerapkan kurikulum 2013 akan tetapi pengetahuan guru-guru mengenai HOTS masih rendah terutama dalam membuat alat evaluasi yang berkatagori HOTS. Oleh karena iitu maka diperlukan pelatihan HTS bagi guru-guru SMAN Negeri 05 Tinggi Moncong. 
Hasil observasi dan wawancara lainnya, tim pengabdi telah memperoleh informasi bahwa para guru di SMAN Negeri 05 Tinggi Moncong tersebut sangat berharap akan ada kegiatan pelatihan pembuatan instrumen evaluasi berbasis HOTS. Mereka secara terbuka mengakui bahwa instrumen evaluasi berbasis HOTS sangat diperlukan untuk meningkatkan kompetensi mereka. Pemahaman dan keterampilan pembuatan instrumen evaluasi berbasi HOTS sangat penting untuk meningkatkan kualitas pembelajaran yang selanjutnya akan meningkatkan prestasi belajar peserta didik. Oleh karena itu, kegiatan PKM ini berupa pelatihan pembuatan instrumen evaluasi berbasis HOTS menjadi sangat penting dan mendesak untuk dilakukan di SMAN Negeri 05 Tinggi Moncong demi kelancaran terlaksananya program pemerintah yakni terselenggaranya proses pembajaran yang efektif di sekolah-sekolah dalam lingkup Kementerian Pendidikan dan Kebudayaan. Oleh karena itu, tim pelaksana kegiatan PKM ini bersama guru-guru dan kepala SMAN Negeri 05 Tinggi Moncong sebagai mitra dalam kegiatan ini telah menentukan persoalan prioritas yang harus diselesaikan yaitu pelatihan pembuatan instrumen evaluasi berbasis HOTS.

1. Apa saja prinsip dan langkah-langkah teknis penyusunan instrumen evaluasi berbasis HOTS?

2. Bagaimana format instrumen evaluasi berbasis HOTS?

3. Apakah guru dapat melakukan praktik penyusunan instrumen evaluasi berbasis HOTS? Permasalahan-permasalahan mitra tersebut akan diselesaikan selama pelaksanaan program PKM ini di SMAN Negeri 05 Tinggi Moncong.

\section{METODE YANG DIGUNAKAN}

\section{Solusi}

Solusi yang ingin dicapai setelah kegiatan PKM ini adalah guru:

1. Memahami tentang prinsip dan langkah-langkah pembuatan instrumen evaluasi berbasis HOTS.

2. Memahami format dan komponen-komponen instrumen evaluasi berbasis HOTS.

3. Terampil menyusun instrumen evaluasi berbasis HOTS
4. Minimal $90 \%$ peserta pelatihan PKM mampu menyusun instrumen eavluasi dengan baik.

\section{Target Luaran}

Target luaran yang ingin dihasilkan setelah kegiatan pelatihan/workshop PKM ini dilakukan adalah:

1. Terciptanya instrumen evaluasi berbasis HOTS yang dapat digunakan oleh guru-guru SMAN Negeri 05 Tinggi Moncong

2. Laporan kegiatan PKM pelatihan pembuatan instrumen evaluasi berbasis HOTS bagi guru SMAN Negeri 05 Tinggi Moncong.

\section{Metode Pelaksanaan}

Mitra sasaran yang akan dilibatkan dalam kegiatan workshop ini adalah: guru-guru dan kepala SMAN Negeri 05 Tinggi Moncong. Mereka inilah menjadi mitra sasaran yang strategis dalam kegiatan ini terutama guru-guru karena guru-gurulah yang akan menggunakan instrumen evaluasi berbasis HOTS dalam ppembelajaran. Kepala sekolah juga menjadi khalayak sasaran karena kepala sekolah dapat memberi instruksi kepada guru-guru untuk dapat merancang dan menggunakan instrumen evaluasi sebagai upaya untuk meningkatkan mutu pembelajaran.

Metode yang diterapkan dalam pelaksanaan PKM ini adalah dengan menerapkan metode pemaparan atau ceramah bervariasi, tanya jawab, diskusi, dan

praktik/unjuk kerja. Selanjutnya diteruskan sebagai tugas mandiri di luar kelas selama 5 hari. Setelah 5 hari, para peserta akan melaporkan hasil praktiknya berupa produk instrumen evaluasi secara lengkap dan benar. Semua kegiatan tersebut dilakukan secara daring disebabkan kondisi pandemi COVID 19.

Kegiatan pertama adalah tim PKM mereview peserta berkaitan dengan pemahaman membuat soal HOTS berdasarkan pengetahuan mereka. Hal ini akan menjadi dasar bagi tim PkM untuk mengetahui bagaimana kemampuan guru peserta kegiatan dalam mengembangkan soal HOTS. Hasil kegiatan ini menunjukkan bahwa masih bayak peserta kegiatan yang belum dapat menyusun dan memahami soal HOTS yang sesuai dengan 
indikator. Hasil dari review ini menjadi dasar pelaksanaan kegiatan selanjutnya.

Kegiatan kemudian dilanjutkan dengan pemaparan materi mengenai soal HOTS oleh tim PkM. Tim menjelaskan tentang evaluasi hasil belajar khususnya tentang soal HOTS yang sesuai dengan kurikulum 2013. Hal yang dibahas dalam pertemuan ini adalah bagaimana konsep dari soal HOTS, bagaimana ciri dan karakteristik soal HOTS, dan cara mengembangkan soal HOTS sesuai dengan kompetensi dasar dan indikator.

Selanjutnya peserta melakukan praktik membuat soal HOTS sesuai dengan kompetensi dasar dan indikator yang ada. Kegiatan praktikum ini dibimbing oleh Tim PkM. Peserta kegiatan mulai memahami cara menyusun soal HOTS. Peserta melakukan diskusi dengan peserta lain dan bertanya langsung dengan tim PkM terkait hal yang belum dipahami. Pada tahap ini juga peserta kegiatan mulai melakukan perbaikan pemahaman terhadap soal HOTS yang dipahami saat review di awal kegiatan. Sebagian besar soal yang dibuat oleh peserta hanya berada pada level sedang.

\section{PELAKSANAAN DAN HASIL KEGIATAN}

Berdasarkan pengamatan tim PkM, peserta kegiatan menunjukkan perhatian terhadap materi yang disajikan. Setelah pemaparan, kegiatan dilanjutkan dengan sesi tanya jawab. Pada sesi ini, peserta menunjukkan sikap yang aktif dan antusias dengan materi ini. Beberapa pertanyaan diajukan oleh peserta kegiatan diantaranya:

1. Apakah soal HOTS itu berarti sulit?

2. Soal HOTS yang telah berulang apakah masih tergolong HOTS

3. Soal HOTS Memiliki stimulus, apakah setiap soal HOTS harus Memiliki stimulus?

4. Bagaimana kata kerja operasional untuk soal evaluasi HOTS yang cocok?

Tim PKM memberikan tanggapan untuk pertanyaan peserta sebagai berikut:

1. Soal HOTS bukan berarti sulit, tapi harus memiliki karakteristik seperti yang telah dijelaskan pada pemaparan materi yaitu
Memiliki stimulus yng kontekstual, meuntut cara berpikir yang logis, kreatif, sistematik, dan metakognisi. Sebagai contoh, untuk mengetahui arti sebuah kata yang tidak umum (uncommon word) mungkin memiliki tingkat kesukaran yang sangat calltinggi, tetapi kemampuan untuk menjawab permasalahan tersebut tidak termasuk higher order thinking skills. Dengan demikian, soal-soal HOTS belum tentu soalsoal yang memiliki tingkat kesukaran yang tinggi.

2. Soal HOTS yang berulang bagi peserta yang sama atau soal yang telah dipelajari oleh siswa sebelumnya bisa menjadi tidak bersifat HOTS lagi. Hal ini disebabkan dalam penyelesaiaannya siswa tidak lagi berpikir sesuai yang dikehendaki dalam penuyelesaian soal HOTS, tetapi sekedar me-recall pengetahuan saja. Jadi seharusnya soal dibuat bervariasi, misalnya mengubah stimulusnya.

3. Soal HOTS harus Memiliki stimulus agar pendidik dapat mengikuti proses berpikir siswa dalam menyelesaikan soal. Stimulus tidak boleh menyediakan jawaban secara langsung, tetapi bisa menjadi sumber data untuk menyelesaikan soal. Stimulus juga harus bersifat kontekstual berkaitan dengan masalah masalah yang sedang dihadapi di kehidupan sehari hari siswa. Pada penyusunan soal-soal HOTS umumnya menggunakan stimulus. Stimulus merupakan dasar untuk membuat pertanyaan. Dalam konteks HOTS, stimulus yang disajikan hendaknya bersifat kontekstual dan menarik. Stimulus dapat bersumber dari isu-isu global seperti masalah teknologi informasi, sains, ekonomi, kesehatan, pendidikan, dan infrastruktur. Stimulus juga dapat diangkat dari permasalahan-permasalahan yang ada di lingkungan sekitar satuan pendidikan seperti budaya, adat, kasus-kasus di daerah, atau berbagai keunggulan yang terdapat di daerah tertentu. Kreativitas seorang guru sangat mempengaruhi kualitas dan variasi stimulus yang digunakan dalam penulisan soal HOTS.

4. Pada pemilihan kata kerja operasional (KKO) untuk merumuskan indikator soal HOTS, 
hendaknya tidak terjebak pada pengelompokkan KKO.Sebagai contoh kata kerja 'menentukan' pada Taksonomi Bloom ada pada ranah $\mathrm{C} 2$ dan C3. Dalam konteks penulisan soal-soal HOTS, kata kerja 'menentukan' bisa jadi ada pada ranah C5 (mengevaluasi) apabila untuk menentukan keputusan didahului dengan proses berpikir menganalisis informasi yang disajikan pada stimulus lalu peserta didik diminta menentukan keputusan yang terbaik. Bahkan kata kerja 'menentukan' bisa digolongkan C6 (mengkreasi) bila pertanyaan menuntut kemampuan menyusun strategi pemecahan masalah baru. Jadi, ranah kata kerja operasional (KKO) sangat dipengaruhi oleh proses berpikir apa yang diperlukan untuk menjawab pertanyaan yang diberikan. Pada penyusunan soal-soal HOTS umumnya menggunakan stimulus. Stimulus merupakan dasar untuk membuat pertanyaan.

Ada beberapa soal yang dibuat sebelumnya (review diawal kegiatan) yang dinyatakan oleh peserta sebagai soal HOTS dengan level $\mathrm{C} 4$ yaitu analisis, namun melalui diskusi diketahui bahwa soal tersebut masih termasuk dalam level C3. Di samping itu, berdasarkan hasil pengamatan pada saat praktik peserta masih ada yang membuat soal belum sesuai dengan indikator HOTS. Oleh karena itu, pada praktik ini peserta dibimbing dan diberi arahan untuk membuat soal HOTS yang benar. Hasil pengamatan tim pada bagian kegiatan ini adalah diskusi yang dilakukan oleh peserta berjalan dengan baik, ditandai dengan aktifnya peserta dalam mengajukan pertanyaan dan tanggapan terkait soal HOTS. Pada akhir kegiatan, peserta dapat membuat soal HOTS yang sesuai dengan indikator. Level soal yang dibuat peserta kegiatan sudah sesuai yaitu berada pada level $\mathrm{C} 4 \mathrm{ke}$ atas.

Selama kegiatan berlangsung, peserta menunjukkan partisipasi yang tinggi. Peserta merupakan guru SMA Negeri 5 Tinggi Moncong dari berbagai bidang studi, sehingga suasana diskusi lebih menarik. Partisipasi ini ditunjukkan oleh banyaknya peserta yang memberikan tanggapan ataupun pertanyaan berkaitan dengan instrument berbasis HOTS. Besarnya minat peserta juga terekam melalui angket yang dibagikan kepada peserta. Rata-rata peserta memberikan respon sangat memuaskan baik dari segi metode penyampaian maupun manfaat dari materi yang disampaikan.

Kegiatan ini berjalan dengan lancar sesuai yang direncanakan dari awal hingga akhir pelaksanaan. Faktor yang mendukung hal tersebut terutama adalah antusias dan partisipasi peserta kegiatan. Mereka sangat bersemangat didorong oleh kebutuhan peningkatan kemampuan berkaitan dengan penyusunan evaluasi hasil belajar berbasis HOTS yang memang menjadi tuntutan pendidikan dewasa ini. Guru harus bisa meningkatakan kemampuan berpikir kritis siswa melalui proses pembelajaran yang menumbuhkan kemampuan berpikir tingkat tinggi atau berpikir kritis siswa. Disamping itu, guru juga harus mampu menyusun instrument evaluasi hasil belajar siswa berbasis HOTS.

\section{KESIMPULAN}

Kegiatan ini dapat meningkatkan kemampuan guru dalam menyusun instrument evaluasi hasil belajar berbasis HOTS. Metode yang digunakan efektif dalam mencapai tujuan pelaksanaan kegiatan.

\section{DAFTAR PUSTAKA}

Arikunto, S. 2006. Prosedur Penelitian: suatu pendekatan praktik, edisi revisi VI.. Rineka Cipta: Jakarta.

Ariyana, Y., Pudjiastuti, A., dan Bestary, R. (2018)

Buku Pegangan Pembelajaran Berorientasi pada Ketrampilan Berpikir Tingkat Tinggi, Modul Suplemen Program Pengembangan Keprofesian Berkelanjutan Melalui Pendidikan dan Pelatihan, Direktorat Jenderal Guru dan tenaga Kependidkan, kementerian Pendidikan dan Kebudayaan

Direktorat Jenderal Pendidikan Tinggi Depdiknas, 2011.Petunjuk TeknisPelaksanaan Pengabdian edisi VIII.Dirjen Dikti: Jakarta.

Furchan, A. 1982. Pengantar Penelitian dalam Pendidikan. Usaha Nasional: Surabaya. 
196 Jurnal Dedikasi, Vol. 22, No. 2, 2020 (192-196)

Kemendikbud, 2013.Buku Guru untuk SD Kelas 4, 5, dan 6 Berdasarkan Kurikulum 2013. Kemendikbud: Jakarta.

Sulistyorini, S. 2007.Model Pembelajaran IPA Sekolah Dasar dan Penerapannyadalam KTSP.Tiara Wacana: Yogyakarta.

Suparmin, Wahyuningrum, dan Mulyono, S. 2013.Seri Character Building:PAKEM Tema 1 s.d. 9 untuk SD dan MI Kelas IV Sesuai Kurikulum2013. Mediatama: Surakarta.

Susilo, H., Chotimah, H., dan Sari, Y.D. 2008. Penelitian Tindakan Kelas: sebagai sarana pengembangan keprofesionalan guru dan calon guru. Bayumedia Publishing: Malang. 